\title{
院內油田の錅井に就きて
}

(昭和 11 年 5 月 3 日石油技街協會秋田满演會講演)

北原喜作*

院入油时は秋田縣由利郡院內村に在り, 狗越線蕏平澤驛南方約 $4,000 \mathrm{~m}$ の地點より之を中心として延長腩北約 $3,000 \mathrm{~m}$ に互り其地域は同村大字院 內大字小國机つてなる。

此油田には現在日本石油秼式會注の外, 中野興業株式會注，地石油陎式會 社，大日本石油鑛業株式會社等が夫く稼行してるる。以下日本石油株式會社 の鳘井に就いて，而も其队現在主として探掘してるる小國方面の深度 $700 \mathrm{~m}$ 乃至 $800 \mathrm{~m}$ の鳘井に於ける坑內作業に就いて述べんとす。

\section{1. 油層及水層の狀態}

此區域の油層は地表より約 $700 \mathrm{~m}$ より $800 \mathrm{~m}$ 附近まで約 $100 \mathrm{~m}$ の間に 介在し, 其厚きの喲 $2 \mathrm{~m}$ 薄ものは $0.10 \mathrm{~m}$ に足らざる薄曆が多數に 存在する。合油曆は何れる砂曆にして粗粒のるのあり, 微粒のものあり, 或 は含油多量なるものあり，筫弱なるるのありて一梯ならさるも概して微粒砂 の油層恃含油多量なるが如し。

現在まで 34 坑，成功せる探油々展の非均深度は $726.30 \mathrm{~m}$ から $768 \mathrm{~m}$ までになつてなる。水層は口式掘進なるが第其位置及び出水量は扂確に判明 し居らざるも，小國藿綱式 1 號本に於ては坑口ょり $21 \mathrm{~m}, 33 \mathrm{~m}, 156 \mathrm{~m}, 232 \mathrm{~m}$, $247 \mathrm{~m}, 268 \mathrm{~m}, 340 \mathrm{~m}, 477 \mathrm{~m}, 520 \mathrm{~m}, 540 \mathrm{~m}$ の如く多慗砂虚よりの出水を見 てるる。而して其量は $247 \mathrm{~m}$ に於て一書夜 $10.8 \mathrm{kl}, 340 \mathrm{~m}$ に於て $13 \mathrm{kl}$ とな

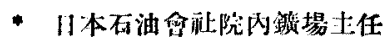


つて居る。油層に近き最下部の水庴としては小國口式 2 號井に於て $615.50 \mathrm{~m}$ にて一諳夜 $12 \mathrm{kl}$ の出水を見てるる。

\section{2. 掘整}

掘㢣には高さ $26 \mathrm{~m}, 32 \mathrm{~m}$ 及び $34 \mathrm{~m}$ 鐵製㮴を，ロータリーマシンは 15 年型及びュニバーザルの 20 时ロータリーマシンをスラッシュポンプは $5^{3} / 4^{\prime \prime} \times 12^{\prime \prime}$ ガンボン型パッーボンプを又網式㗹金具は $6^{\prime \prime}$ 又は $43 / 8 ”$ を夫

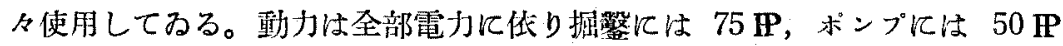
の電動機を使用してるる。

掘鳘中ポンプは通常 1 臺にしてセメント水止の際セメント混合，椪に壓揆 用として 1 臺を据付く。掘進中水止（34 坑平均水止深菖 $684 \mathrm{~m}$ ) 委では口 式によりて掘進し，其队 $635 \mathrm{~m}$ より水止深度 $684 \mathrm{~m}$ までは各坑井とも水止 地質精查の䉆コーアー掘をしてるる。水止管は通常 $85 / 8^{\prime \prime}$ 管にて水止後網式

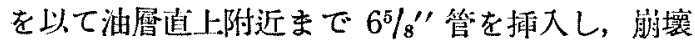
防止の上，更に口式に代へコーアー掘を以て掘止 深度 (34 坑平均深度 $770 \mathrm{~m}$ ) まで掘進し, $4^{3} / 4^{\prime \prime}$ 鉃 孔管を投入して 4" 仕上げにしてるる。此の油田 は地堎より約 $450 \mathrm{~m}$ 乃至 $500 \mathrm{~m}$ 附近までは處各 飞砂を介在する砂筫项岩曆にして以下砂之砂筫项

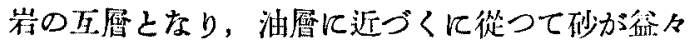
發達してるる，硬筫のものなく蹅めて軟筫の地層

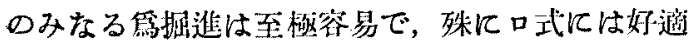
の地蝔抏と思つてるる。

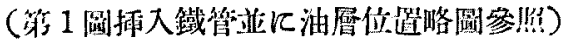

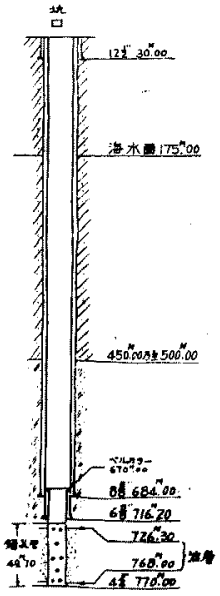

第 1 圆 雨入鐵管出に 油層位鯋略阔 其掘進秦を示せば第 1 表の如し。 
第 1 表 掘 進率 比 較 表

\begin{tabular}{|c|c|c|c|}
\hline & 堀 進 & 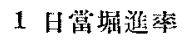 & 1 日雷實堀進育 \\
\hline 口] & 坑口 ヨり $635.80 \mathrm{~m}$ マデ & $62.52 \mathrm{~m}$ & $78.85 \mathrm{~m}$ \\
\hline 口式コーフ堀 & $635.80 \mathrm{~m} \exists$ \ $684.00 \mathrm{~m} マ{ }^{*}$ & $8.78 \mathrm{~m}$ & $10.77 \mathrm{~m}$ \\
\hline 悢 & $684.00 \mathrm{~m}$ 以下 $65.80 \mathrm{~m}$ & - & $11.32 \mathrm{~m}$ \\
\hline
\end{tabular}

(以上 34 琓の本均なり)

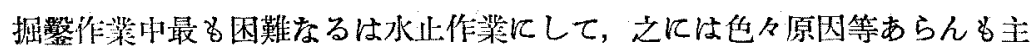
として水止附近に適當なる地翼，即ち良質の粘土若しくは頁岩厤の極めて己

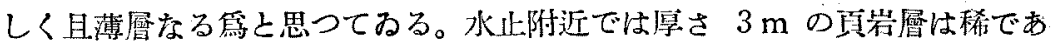

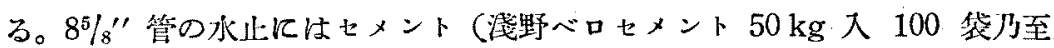
150 袋最近は 100 袋）を使用してるる。其方法はチュービング式及び二栓式

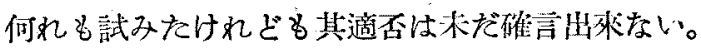

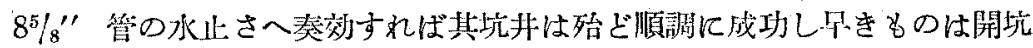
より1筬月で出油成功してるる。之等順調成功北 13 坑の開坑より成功まで の平均所要日數は 42 日になつてるる。然るに水止が失敗し二次，三次と水

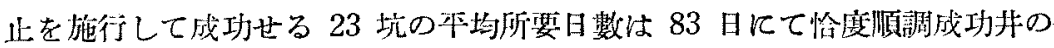
約 2 倍の日數を要してるるてと〉なる。以上 33 坑の本均所要日數は 66.76 日に疗つてるる。

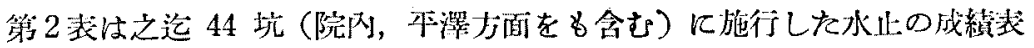
である。

表中「坑底」「引揚」とせるは水止管を坑废に笑かした場合と坑底附近が 砂で水止に不適當の䉆，適當の地貿の處まで引揚げた場合の事である。

結局セメント水必の成功率は $61.7 \%$ 迫止は $80 \%$ 网省永均して $68.6 \%$ と 言ふ事になつてるる。即ち 44 坑の坑井に鍺して 70 回の水归を施行したの である。 
北原喜 作

第 2 婁 水 止成 績 一 㯺 表

\begin{tabular}{|c|c|c|c|c|c|}
\hline 水止智の大さ & 水止方式 & $\begin{array}{l}\text { 水止管虚 } \\
\text { 位 䈯 }\end{array}$ & 完 & ，否 & 竐 \\
\hline $113 / 4^{\prime \prime}$ セメント止 & $\begin{array}{l}\text { 丁 式 } \\
\text { 二 枉 }\end{array}$ & $\begin{array}{l} \begin{cases}\text { 坑 } & \text { 底 } \\
\text { 引 } & \text { 揚 }\end{cases} \\
\begin{cases}\text { 坑 底 } \\
\text { 引 }\end{cases} \end{array}$ & $\begin{array}{l}2 \\
- \\
-\end{array}$ & $\begin{array}{r}- \\
1 \\
- \\
-\end{array}$ & $\begin{array}{r}2 \\
1 \\
- \\
-\end{array}$ \\
\hline 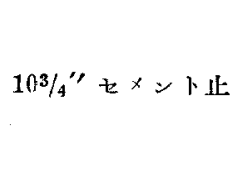 & $\begin{array}{l}\text { 式 } \\
\text { 柽 }\end{array}$ & $\begin{array}{l}\left\{\begin{array}{l}\text { 底 } \\
\text { 引 }\end{array}\right. \\
\left\{\begin{array}{l}\text { 茋 } \\
\text { 可 }\end{array}\right.\end{array}$ & $\begin{array}{l}2 \\
- \\
- \\
-\end{array}$ & $\begin{array}{l}- \\
- \\
-\end{array}$ & $\begin{array}{l}2 \\
- \\
- \\
-\end{array}$ \\
\hline$\delta 5 / s^{\prime \prime} セ x ン 1 . ⿻ 上 丨$ & $\begin{array}{l}\text { 式 } \\
\text { 栓 }\end{array}$ & 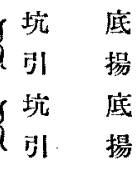 & $\begin{array}{r}18 \\
5 \\
1 \\
-\end{array}$ & $\begin{array}{l}9 \\
4 \\
2 \\
1\end{array}$ & $\begin{array}{r}27 \\
9 \\
3 \\
1\end{array}$ \\
\hline $6^{5} / 8^{\prime \prime}$ セメント止 & $\begin{array}{l}\mathrm{T} \text { 式 } \\
=\text { 烃 }\end{array}$ & 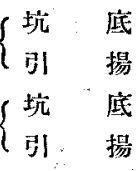 & $\begin{array}{l}1 \\
- \\
- \\
-\end{array}$ & $\begin{array}{l}1 \\
- \\
- \\
-\end{array}$ & $\begin{array}{l}2 \\
- \\
- \\
-\end{array}$ \\
\hline 七 & 止 & 訫 & 29 & 18 & 47 \\
\hline $8^{5} / 8^{\prime \prime}$ 迫 此 & 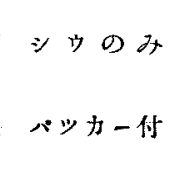 & $\begin{array}{l}\left\{\begin{array}{l}\text { 坑 } \\
\text { 引 }\end{array}\right. \\
\left\{\begin{array}{l}\text { 坑 } \\
\text { 引! }\end{array}\right.\end{array}$ & $\begin{array}{l}2 \\
- \\
- \\
-\end{array}$ & $\begin{array}{r}- \\
- \\
2 \\
-\end{array}$ & $\begin{array}{r}2 \\
-- \\
-\end{array}$ \\
\hline $6^{5} / 8^{\prime \prime}$ 䞟 此 & 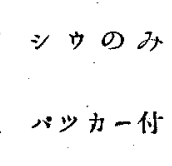 & $\begin{array}{l}\left\{\begin{array}{l}\text { 坑 } \\
\text { 引| }\end{array}\right. \\
\left\{\begin{array}{l}\text { 坑 } \\
\text { 引 }\end{array}\right.\end{array}$ & $\begin{array}{r}2 \\
1 \\
10 \\
3\end{array}$ & $\begin{array}{r}- \\
- \\
1\end{array}$ & $\begin{array}{r}2 \\
1 \\
11 \\
4\end{array}$ \\
\hline $4^{3} / 4^{\prime \prime}$ 速 : 此 & $\begin{array}{l}\text { シウのみ } \\
\text { パッカー仯 }\end{array}$ & $\begin{array}{l}\left\{\begin{array}{l}\text { 坑 } \\
\text { 引l }\end{array}\right. \\
\left\{\begin{array}{l}\text { 坑 } \\
\text { jl }\end{array}\right.\end{array}$ & $\begin{array}{l}- \\
- \\
1\end{array}$ & $\begin{array}{l}- \\
- \\
- \\
-\end{array}$ & $\begin{array}{l}- \\
- \\
- \\
1\end{array}$ \\
\hline 生 & It: & nt & 19 & 4 & 23 \\
\hline 合 & & it & 48 & 22 & 70 \\
\hline
\end{tabular}

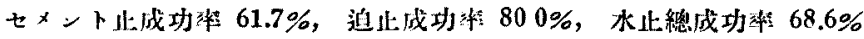


玆に示した迫止とは普通良質の粘土層, 又は頁岩曆にスチールシゥ, ロン グシウ若しくは段付シウの如きシウを打込み，其迫达を以てする所謂迫止と

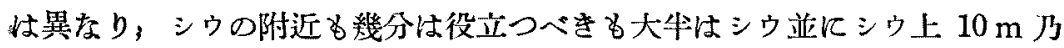
至夫以上の相當長い間鐵管と坑壁との間に砂其他の崩壞物を生じ，之が水壓 等に上り㻺縮せられ逐に一つのウォータータイトの狀態となるるのと思は れる。

パツカーとは第 2 圖の如き構造のも のとし, 沈澱の足踏りとなる沈潵促進 物に過ぎない。

$6^{5} / 8^{\prime \prime}$ 及 $4^{3} / 4^{\prime \prime}$ の迫止に於てシウを 引掦げて 5 回名成功してなるのは普通 の迫止と異なり，上記の如きウォータ ータイトの狀態となり臨水せられたる のと思つてるる。

以上 44 坑に對し水止施行回數 70 回の成續をり。

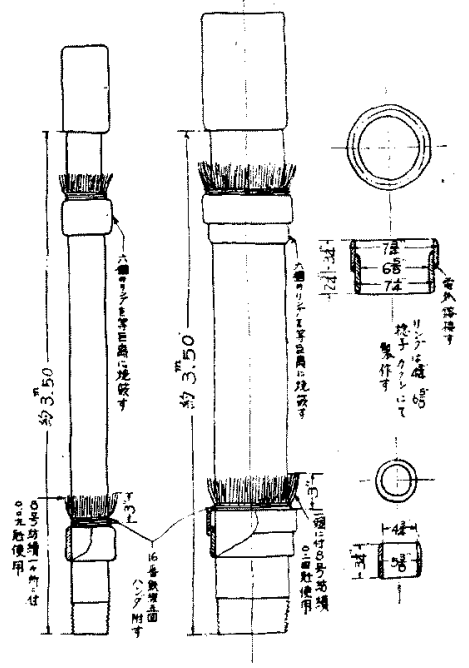

第 2 團 バッカー略四

\section{3. 探}

油

採油は全部チュービングを插人してォイルホンンプに低り單瀷, 又はボンピ ングパワー汲みにしてるる。チユービングは $2 \frac{1}{2}{ }^{2 \prime}$ オイルポンプは全部ラ ンダス式を使用してねる。成功當時湛油の多いるのは坑口より $150 \mathrm{~m}\left(4^{3} / 4^{\prime \prime}\right.$ 管內等では $50 \mathrm{~m}$ ) 附近まで上昇して來る事がある。故にボンプの位置は淺 レもので $250 \mathrm{~m}$, 深をも $500 \mathrm{~m}$, 平均 $365 \mathrm{~m}$ になつてねる。

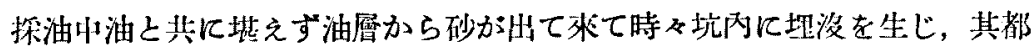
度浚渫せねばならぬ。僅か 30 数牨の油非にて常に 2 坑乃至 3 坑は浚渫して 
みる跃態である。

最近 2 箇月牛に於ける油井故障を示せば第 3 表の如し。

油層部㨂入の制孔管は最初孔徑 $1 / 2$ "乃至 $3 / 8$ "なりしが，鑚孔管を通して

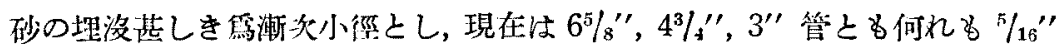
として孔列及孔距 第 3 家 最近 2 ケ月半に於ける油井故降表 は $6^{5 \prime}{ }_{8}^{\prime \prime}$ 管に於て 6 列孔距 $4^{\prime \prime}, 4^{3} /^{\prime \prime}$ 管に於て 5 列孔距 $3^{\prime \prime}, 3^{\prime \prime}$ 管に於て

4 列孔距 $3^{\prime \prime}$ とし

\begin{tabular}{|c|c|c|}
\hline 浚 & 1 ケ月 1 坑當 & $2.64 \mathrm{H}$ \\
\hline ン ダ ス 㨢 替 & $" \prime$ & 1.6 回 \\
\hline チュービン グ 故障 & 25坑 2 タ月牛に & 4 回 \\
\hline $\begin{array}{llll}* & \text { 卜 故 障 }\end{array}$ & ' & 2 国 \\
\hline ウオーキングヴフルヴボール & $" \prime$ & 3 可 \\
\hline ウオーキングヴフルヴシート & $" \prime$ & 1 回 \\
\hline
\end{tabular}

(以上油井 25 坑の本均なり)

てるる。或坑井に於て孔徑 $3 / 16 "$ を使用して油为水子出が惡かつたと言ふ例 るすり，哩野，大日本石油會新に於て「スクリーンパイプ」を使用し，知張

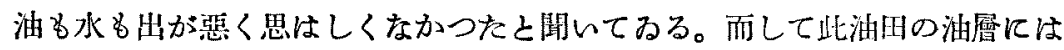
上記の如を鑚孔管を以て道度と思つてるる。

\section{4. 酚井上より見たる本油田の特異性}

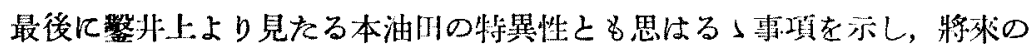
御示数を肴然する次第である。

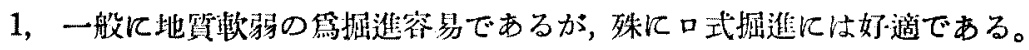

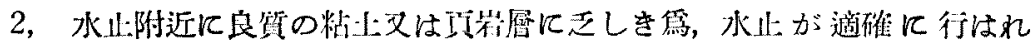
ない。

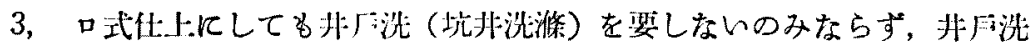
は反つて能壊を唀致する枈がある。

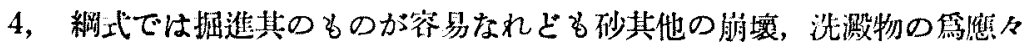




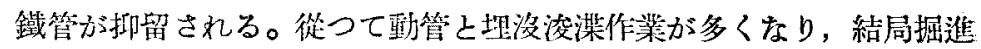
率の惡い多のになる。

5, 上記砂其他の崩壞物の沈搌性を利用して沈澱迫止の進水が應々奏效 す。

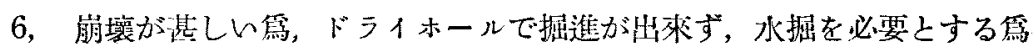
試油試水に不便なり。

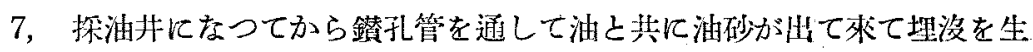
じ，時々㴭渫せねばならぬ。之が㢰繁に繰返される場合，遂にはケー ビンダを起して應ふケーシングまで明げられ，探油不能に陷り改修す べからざる大障害を來す事がある。

以上の冈 2 及 7 項は最む著しい特異性であり，最も笘心困難してるるとこ ろにして研究を要する事項である。 